Int. J. Electrochem. Sci., 14 (2019) $6948-6975$

International Journal of

ELECTROCHEMICAL

SCIENCE

www.electrochemsci.org

\title{
A Study on the Water Splitting using Polymer Electrolyte Membrane for producing Hydrogen and Oxygen
}

\author{
Chang-Hoon Je, Hyung-Man Kim* \\ Department of Electronic Telecommunication, Mechanical \& Automotive Engineering and High \\ Safety Vehicle Core Technology Research Center, INJE University, 197 Inje-ro, Gimhae-si, \\ Gyeongsangnam-do 50834, Republic of Korea \\ *E-mail: mechkhm@inje.ac.kr
}

doi: $10.20964 / 2019.07 .64$

Received: 4 March 2019 / Accepted: 10 May 2019 / Published: 10 June 2019

Hydrogen is expected to be the clean and sustainable fuel as well as the most promising energy carrier. Water splitting using polymer electrolyte membrane have studied numerically and experimentally for producing hydrogen and oxygen by electrolysis in conjunction with intermittent renewable energies. In this study, a control-oriented model for polymer electrolyte membrane electrolyzer are developed to calculate mole balance and electrochemical reaction between at the anode and at the cathode. Numerical simulations are performed using MATLAB ${ }^{\circledR}$ and Simulink ${ }^{\circledR}$ software packages. The electrolyzer test station equipped with flow, temperature and power controllers are manufactured to evaluate the flow and temperature characteristics of circulating water, the uniformity of the pressure over the cell area, then enhance the performance of polymer electrolyte membrane electrolyzer. DC power supply can simulate experimentally the power of renewable energies. The numerical and experimental results are capable of characterizing the flow and temperature characteristics of circulating water and enhancing the performance of polymer electrolyte membrane electrolyzer, then developing the highly efficient control strategy. This polymer electrolyte membrane electrolyzer will be combined with polymer electrolyte membrane fuel cell to establish a regenerative fuel cell with the integrated control system.

Keywords: water splitting; hydrogen; polymer electrolyte membrane electrolyzer; electrochemical reaction; regenerative fuel cell

\section{FULL TEXT}

(C) 2019 The Authors. Published by ESG (www.electrochemsci.org). This article is an open access article distributed under the terms and conditions of the Creative Commons Attribution license (http://creativecommons.org/licenses/by/4.0/). 